\title{
Odour Abatement in Sewage Water: A Tree Based Biological Approach
}

\author{
M. Prasanthrajan*, A. Balasubramanian and K. T. Parthiban \\ Forest College and Research Institute, Tamil Nadu Agricultural University \\ Mettupalayam - 641301 Coimbatore, Tamil Nadu, India \\ *Corresponding author
}

\section{A B S T R A C T}

\begin{tabular}{|l|}
\hline K e y w o r d s \\
$\begin{array}{l}\text { Sewage, odour, } \\
\text { abatement, } \\
\text { biological approach, } \\
\text { trees }\end{array}$ \\
\hline Article Info \\
\hline $\begin{array}{l}\text { Accepted: } \\
18 \text { May } 2020 \\
\text { Available Online: } \\
\text { 10 June } 2020\end{array}$ \\
\hline
\end{tabular}

An investigation has been carried out to develop a biological treatment technology for the removal of odourous compounds from domestic sewage water. Under aerobic condition, free molecular oxygen is used by microbes as electron acceptor and produce water. Under anaerobic condition, if neither oxygen nor nitrate $\left(\mathrm{NO}_{3}{ }^{-}\right)$is present, microbes tend to use sulphate $\left(\mathrm{SO}_{4}{ }^{2-}\right)$ as electron acceptor and generate volatile $\mathrm{H}_{2} \mathrm{~S}$. Thus cause odour problem. The usual practice adopted by many sewage treatment plants is vigorous aeration. The oxidation of $\mathrm{H}_{2} \mathrm{~S}$ under highly aerobic condition generates sulphuric acid. But, a group of sulphur bacteria oxidize $\mathrm{H}_{2} \mathrm{~S}$ into elemental sulphur without producing sulphuric acid. This elemental sulphur is not used by sulphate reducing bacteria. Thus disrupts the cycle by arresting the formation of $\mathrm{H}_{2} \mathrm{~S}$. In our study Acidithiobacillus ferrooxidans and Acidithiobacillus thiooxidans $\left(5 \% \mathrm{v} / \mathrm{v}\right.$ ) in combination played a perfect role in oxidizing the $\mathrm{H}_{2} \mathrm{~S}$ into elemental sulphur thus it prevents odour formation from sewage water. The activity of microbes will be more during summer and they might require more oxygen. The increase in microbial activity would deplete the oxygen and makes the bacteria to look for an alternative oxygen source alleviate an odour problem. Thus, planting tree species like Terminalia arjuna, Millingtonia hortensis, Hibiscus tiliaceus and Melia dubia across the sewage drain/sewage lagoon would keep the sewage system aerated and support the microbial growth and thereby solve odour problem.

\section{Introduction}

Odour has become a major environmental issue worldwide with increasing public demand for better control of odorous emissions from municipal sewage water. Odour annoyance affects the population directly and there is a trend that more and more people are becoming less tolerable with obnoxious odour. Odour is the most common problem encountered in many sewage collection system and open drain that carries domestic sewage water. In most cases, this odour is the result of mixing of industrial waste water and domestic sewage water and due to anaerobic bacterial metabolism. Biological processes in wastewater of sewer networks under anaerobic conditions result in the production of low molecular and volatile substances.

When emitted to the atmosphere, a number of these volatile organic and inorganic compounds may cause malodours. Particularly when occurring in dense populated urban areas, the problem of 
malodour must be managed to observe public requirements and current standards and guidelines. Fermentation and sulfate reduction are the main processes responsible for the formation of odorous compounds (Thorkild Hvitved-Jacobsen et al., 2005).

The statement made by Thistlethwayte and Goleb (1972) was based on rather limited measurements. However, it agrees with the theory concerning the production of odorous substances from anaerobic microbial processes. Other authors, primarily dealing with odours related to wastewater treatment, have also concluded that $\mathrm{H}_{2} \mathrm{~S}$ can be considered a relevant indicator for an odour level (Gostelow and Parsons, 2000). Hydrogen sulphide is the most common cause of odour problem in sewage water. In addition to the rotten egg odour, it also causes corrosion problem in sewage drains/pipes that cause huge money for repairing services and maintenance. Besides, $\mathrm{H}_{2} \mathrm{~S}$ also cause serious health problems to human beings/personnel working/exposed to $\mathrm{H}_{2} \mathrm{~S}$. In the waste water treatment system presence of $\mathrm{H}_{2} \mathrm{~S}$, reduces the effectiveness of treatment system by causing toxicity to the biomass which is essential for any biological treatment system. It is important to notice that $\mathrm{H}_{2} \mathrm{~S}$ loses its characteristic smell at about $50 \mathrm{ppm}$ and no direct possibility for its detection therefore exists. The density of $\mathrm{H}_{2} \mathrm{~S}$ is slightly higher than that of the atmosphere (relative density 34/29). Therefore, $\mathrm{H}_{2} \mathrm{~S}$ has a tendency to accumulate in, for example, pumping stations and manholes. As it is typically not detected by its smell at those concentrations where it is life threatening, instruments or alarm systems for its monitoring must generally be used when working in sewer networks.

Odorous compounds formed in sewer networks or during wastewater treatment are produced by the anaerobic decomposition of organic matter that contains sulfur or nitrogen. Fresh wastewater has a distinctive, somewhat disagreeable odour, which is less objectionable than the odour of wastewater which has undergone anaerobic decomposition. The odorous compounds found in wastewater plants are usually generated by the microbial degradation of complex organic compounds. Under anaerobic conditions, fermentation of fats, polysaccharides and proteins takes place (Hwang et al., 1995). These compounds are hydrolyzed to fatty acids, shorter chain saccharides, amino acids and peptides and then to shorter chain compounds. Fats, oils, greases, volatile fatty acids like acetic, propionic and butyric acid also have sharp odour. Hydrolysis of proteinaceous material and organic sulfur compounds leads to the production of hydrogen sulfide $\left(\mathrm{H}_{2} \mathrm{~S}\right)$ and organic sulfides and disulfides. Domestic wastewater normally contains about 3 to 6 $\mathrm{mg} / \mathrm{L}$ of organic sulfur in proteinaceous matter and additional organic sulfur in the form of sulfonates (about $4 \mathrm{mg} / \mathrm{L}$ ) derived from the house detergents (Boon 1995).

The bacteria responsible for hydrolysis of several substrates with the production of sulfides (Proteus spp., Bacteroides spp. and some Clostridium spp.) are active at a higher redox potential than those which subsequently reduce sulfate to form $\mathrm{H}_{2} \mathrm{~S}$. The reduction of sulfates by sulfate-reducing bacteria (SRB) with the production of $\mathrm{H}_{2} \mathrm{~S}$ is the most important of the odour-generating reactions because this gas is always present when odours are due to septicity, even when this is not the main source of odour. SRBs are heterotrophic bacteria which metabolize sulfate to provide energy for the dissimilation of organic matter, and release sulfide to the solution. They are strictly anaerobic, operating at lower redox (below 2200mV) than fermentation processes, which occur at the same time. They grow at a slower rate than aerobic microorganisms (Lens et al., 
1995). When oxygen or nitrate is present, SRB cannot function. SRB are usually present in wastewater, sludges, submerged surfaces of sewers, holding-tanks, sediments of sewers and anaerobic digestion processes. The amount of sulfide that can be produced by SRB is limited by the initial sulfate concentration found in wastewater or sludge and well as by the presence of nutrients and fermentation products (Hvitved-Jacobsen et al., 1999). The concentration of inorganic sulfate in wastewater varies greatly from area to area, depending on the hardness of ground water.

Odour-producing substances found in domestic wastewater and sludge is small, relatively volatile molecules with a molecular weight of 30 to 150 (Gostelow et al., 2001). The lower the molecular weight of a compound the higher the volatility and potential for emission to the atmosphere. Substances of high molecular weight are usually not particularly odorous and are neither volatile nor soluble. It is noted that the human odour threshold for $\mathrm{H}_{2} \mathrm{~S}$ is very low, about 3 to $5 \mathrm{ppb} . \mathrm{H}_{2} \mathrm{~S}$ is the most important of these compounds; however, the interactions of $\mathrm{H}_{2} \mathrm{~S}$ with other compounds can lead to odour problems that produce even more unpleasant odours (Livermore \& Laing 1998).

Although $\mathrm{H}_{2} \mathrm{~S}$ is commonly found under anaerobic conditions, it is questionable whether this is the major odour at wastewater treatment plants (Suffet et al., 2004). Despite the fact $\mathrm{H}_{2} \mathrm{~S}$ is used as a surrogate for all sulfur odours, its odour threshold concentration is not as low as many other sulfur compounds found in municipal wastewater. Furthermore, $\mathrm{H}_{2} \mathrm{~S}$ is a polar molecule with a structure similar to water and is held in solution via hydrogen bonding. It is only molecular $\mathrm{H}_{2} \mathrm{~S}$ that will lead to odour problems and at neutral $\mathrm{pH}$ approximately $50 \%$ of the total sulfide will be in this form.
At present, most of the developed countries are adopting covered odour emission treatment system where the gases are collected and treated by a variety of chemical scrubbers followed by activated carbon towers. Although chemical scrubbers provide high odour removal efficiencies, they are expensive. Over the last decade, much research has shown that a special blend of bio-culture of the genus Thiobacillus is effective in adsorbing odorous hydrogen sulphide a principal component of sewage air. Biodrainage by trees also a successful system of odour elimination from sewage. The present investigation focused on the development of cost effective and environmentally friendly technology that oxidizes $\mathrm{H}_{2} \mathrm{~S}$ without the use of any chemical reactants.

\section{Materials and Methods}

Sewage water samples were collected from three different locations namely Mettupalayam, Ukkadam and Bhavanisagar of Tamil Nadu, India for the isolation of native microorganisms present in the sewage water. The collected sewage water samples were characterized. Excess activated sewage sludge samples were also collected from Ukkadam sewage treatment plant (old) and stored @ $4^{\circ} \mathrm{C}$ before use. Later, these sludge samples were used for the isolation of Thiobacillus using selective cultutre medium. $2 \mathrm{~g}$ of sewage sludge was transferred to two conical flasks containing $100 \mathrm{ml}$ of selective culture medium (one for Acidithiobacillus ferrooxidans and other for Acidithiobacillus thiooxidans) and incubated in shaker @ 150 $\mathrm{rpm}, 30^{\circ} \mathrm{C}$ for 10 days. After 10 day the microbial cultures $(2 \mathrm{ml})$ was transferred to freshly prepared selective culture medium and stored for further study. Single and mixed cultures of these microorganisms were used for odour removal from sewage water under laboratory study. 
The changes in $\mathrm{pH}, \mathrm{EC}, \mathrm{BOD}, \mathrm{COD}$ and sulphate content of the sewage water were also studied. Changes in $\mathrm{pH}$ were tested to investigate the suitable condition for the growth of Acidithiobacillus ferrooxidans and Acidithiobacillus thiooxidans.

In the odour removal study, $200 \mathrm{ml}$ of sewage water was taken in four different conical flasks (500 ml capacity). First conical flask containing sewage water $(200 \mathrm{ml})$ was maintained as control without adding microbial cultures. Second conical flask was added with Acidithiobacillus ferrooxidans and third with Acidithiobacillus thiooxidans@ @ $10 \% \mathrm{~V} / \mathrm{V}$. In the fourth conical flask, Acidithiobacillus ferrooxidans and Acidithiobacillus thiooxidans were added @ $5 \% \mathrm{~V} / \mathrm{V}$ each. The $\mathrm{pH}$ of the test medium (sewage) was adjusted to $\mathrm{pH}$ 4.0. The change in $\mathrm{pH}$ of the test water (sewage) was recorded after the addition of Acidithiobacillus ferrooxidans and Acidithiobacillus thiooxidans.

Performance of Thiobacillus mixed cultures on water quality were also evaluated in sewage and river water. The ability of tree species (fifteen indigenous) in growing water logged condition was studied. From this, ten tree species were screened to study the influence of excess irrigation (both sewage and river water) on their growth under pot culture experiment. The performance of Hibiscus tiliaceus, Millingtonia hortensis, Pongamia pinnata, Terminalia arjuna, Melia dubia, Neolamarckia cadamba, Azadirachta indica, Thespisia populnea, Ficus religiosa, Muntingia calabura was tested under water logged condition (sewage water). From this study, four tree species (Hibiscus tiliaceus, Millingtonia hortensis, Terminalia arjuna, and Melia dubia) were screened for further investigation. Then the seedlings of these four tree species with uniform seedlings height (30 $\mathrm{cm}$ ) were selected for assessing the changes in their growth under sewage water irrigation. As the growth of these trees (Terminalia arjuna, Millingtonia hortensis, Hibiscus tiliaceus and Melia dubia) not affected under both sewage and river water, they were planted across the sewage drains of Forest College and Research Institute, Mettupalayam, Tamil Nadu to study the changes in growth for about 180 days under natural environment. Then the growth of these four tree species (Terminalia arjuna, Millingtonia hortensis, Hibiscus tiliaceus and Melia dubia) were also tested under mount planting (6 month old seedlings) across sewage drain. Simultaneously changes in sewage water quality were also recorded.

The changes in microbial load of sewage water across the sewage drain planted with Terminalia arjuna, Millingtonia hortensis, Hibiscus tiliaceus and Melia dubia were also studied. Specific rhizosphere microbial load of these tree species were also investigated. Two different approaches for monitoring odour exist: either analytical measurements or sensory measurements. In our study, sensory measurements are performed by methods that relate to the impact of odour, either applying the human nose or electronic detectors (CEN 1999; Sneath and Clarkson 2000; Stuetz et al., 2000).

\section{Results and Discussion}

The sewage water samples collected from Ukkadam, Tamil Nadu had pH 6.93, EC 1.29 $\mathrm{dS} \mathrm{m}{ }^{-1}$. The dissolved oxygen content of the sewage water was $1.70 \mathrm{mg} \mathrm{L}^{-1}$, BOD $63 \mathrm{mg}$ $\mathrm{L}^{-1}$, COD $98 \mathrm{mg} \mathrm{L}^{-1}$ and the Coliform count was $3700 \mathrm{MPN} / 100 \mathrm{ml}$. The sewage water samples collected from Mettupalayam and Bhavanisagar were also acidic in nature (6.81 and 6.79 respectively). The EC of sewage water samples of Mettupalayam was $1.32 \mathrm{dS}$ $\mathrm{m}^{-1}$. The dissolved oxygen content of these two samples was low (3.46 and $4.12 \mathrm{mg} \mathrm{L}^{-1}$ ). 
Activated sludge collected from Ukkadam sewage treatment plant had a $\mathrm{pH}$ of 6.90 , EC $1.35 \mathrm{dS} \mathrm{m}^{-1}$, Total nitrogen $4120 \mathrm{mg} / \mathrm{kg}$, Total phosphorous $3128 \mathrm{mg} / \mathrm{kg}$, with a coliform count of $4500 \mathrm{MPN} / 100 \mathrm{ml}$. Two microbial cultures of Thiobacillus namely Acidithiobacillus ferrooxidans and Acidithiobacillus thiooxidans were isolated from excess activated sewage sludge using selective cultutre medium. In the control (sewage without microbial culture) showed a increase in $\mathrm{pH}$ (4.0 to 6.9) whereas sewage added with Acidithiobacillus ferrooxidans and Acidithiobacillus thiooxidans as separate and mixed culture showed a decrease in $\mathrm{pH}$ (4.0 to 2.1). Acidothiobacillus ferrooxidans could have caused decrease in $\mathrm{pH}$ because of the formation of $\mathrm{Fe}^{3+}$ from $\mathrm{Fe}^{2+}$.

Reduction in $\mathrm{pH}$ of the sewage added with Acidithiobacillus thiooxidans might be due to the formation of $\mathrm{H}_{2} \mathrm{SO}_{4}$ i.e. the elemental sulphur is oxidized into sulphate through direct reaction by Acidithiobacillus thiooxidans. The isolated microbial cultures, Acidithiobacillus ferrooxidans and
Acidithiobacillus thiooxidans are chemoautotrophic bacteria. They use $\mathrm{CO}_{2}$ as carbon source Iron/Sulphur as energy source and they don't require organic nutrients. Also, strict aseptic condition is not necessary for the growth of these bacteria. The growth of these bacteria was not inhibited by changes in $\mathrm{pH}$. The sulphate removal by these microorganisms was also studied. The sulphate removal of Acidithiobacillus ferrooxidans, Acidithiobacillus thiooxidans and mixed cultures were $84.20 \%, 46.13 \%$ and $96.93 \%$ respectively. In the present investigation, the mixed culture was very good in all runs, and that the final removal of sulphates of mixed culture was $96.93 \%$. Biodegradation of $\mathrm{H}_{2} \mathrm{~S}$ gas produces sulphuric acid, which will eventually decrease the $\mathrm{pH}$ of the sewage water and keep the environment acidic that is vital for the most acid tolerant bacteria Acidithiobacillus ferrooxidans and Acidithiobacillus thiooxidans to play a role in reducing the odour. As the mixed culture was effective in eliminating sulphates, this has been used for further investigation.

\begin{tabular}{|c|c|}
\hline $\begin{array}{l}\text { Selective culture medium for } \\
\text { Acidithiobacillus ferrooxidans }\end{array}$ & $\begin{array}{l}\text { Selective culture medium for } \\
\text { Acidithiobacillus thiooxidans }\end{array}$ \\
\hline$\left(\mathrm{NH}_{4}\right)_{2} \mathrm{SO}_{4} \quad: 3.0 \mathrm{~g}$ & $\left(\mathrm{NH}_{4}\right)_{2} \mathrm{SO}_{4} \quad: 3.0 \mathrm{~g}$ \\
\hline $\mathrm{K}_{2} \mathrm{HPO}_{4} \quad: 0.5 \mathrm{~g}$ & $\mathrm{~K}_{2} \mathrm{HPO}_{4}$ \\
\hline $\mathrm{MgSO}_{4} 7 \mathrm{H}_{2} \mathrm{O}: 0.5 \mathrm{~g}$ & $\mathrm{MgSO}_{4} 7 \mathrm{H}_{2} \mathrm{O}: 0.5 \mathrm{~g}$ \\
\hline$: 0.1 \mathrm{~g}$ & $: 0.1 \mathrm{~g}$ \\
\hline $\mathrm{Ca}\left(\mathrm{NO}_{3}\right)_{2} 4 \mathrm{H}_{2} \mathrm{O}: 0.01 \mathrm{~g}$ & $\mathrm{Ca}\left(\mathrm{NO}_{3}\right)_{2} 4 \mathrm{H}_{2} \mathrm{O}: 0.01 \mathrm{~g}$ \\
\hline $\mathrm{FeSO}_{4} 7 \mathrm{H}_{2} \mathrm{O} \quad: 40 \mathrm{~g}$ & Sulphur \\
\hline Deionized water: $1000 \mathrm{ml}$ & Deionized water: $1000 \mathrm{ml}$ \\
\hline $\mathrm{pH} \quad: 2.0$ & $\mathrm{pH}$ \\
\hline
\end{tabular}

The changes in $\mathrm{pH}, \mathrm{EC}$, Dissolved oxygen, Chemical Oxygen Demand, Biological Oxygen Demand, sulphates during the odour removal study is given in Table 1 . Performance of Thiobacillus mixed cultures on water quality were also evaluated in sewage and river water (Table 2). The mixed culture added in both river and sewage water showed a decrease in $\mathrm{pH}$ (Neutral to acidic) and a slight increase in EC (1.27 to $1.35 \mathrm{dS}$

$\left.\mathrm{m}^{-1}\right)$. Addition of these cultures showed a reduction in COD and sulphate (3160 to 104 $\mathrm{mg} \mathrm{L}^{-1}$ ).

The growth performance of Hibiscus tiliaceus, Millingtonia hortensis, Pongamia pinnata, Terminalia arjuna, Melia dubia, Neolamarckia cadamba, Azadirachta indica, Thespisia populnea, Ficus religiosa, 
Muntingia calabura under water logged condition (sewage water) is given in Table 3. The growth of Hibiscus tiliaceus, Millingtonia hortensis, Terminalia arjuna, and Melia dubia were not affected due to sewage water logged condition and the growths of remaining six species were affected. The tree species Hibiscus tiliaceus, Millingtonia hortensis, Terminalia arjuna, and Melia dubia were selected for further study as their growth was not affected due to excess sewage irrigation. Uniform seedlings (30 $\mathrm{cm}$ height) of these tree species Hibiscus tiliaceus, Millingtonia hortensis, Terminalia arjuna, and Melia dubia were selected for assessing the changes in their growth under sewage water. Among these, Melia dubia recorded maximum height of $190 \mathrm{~cm}$ in 180 Days after planting. Terminalia arjuna and Hibiscus tiliaceus showed a growth of $165 \mathrm{~cm}$ in 180 days.

Millingtonia hortensis recorded $76 \mathrm{~cm}$ height in 180 days. Similar experiment was conducted with river water for comparison (Table 3). The growth performance of (Terminalia arjuna, Millingtonia hortensis, Hibiscus tiliaceus and Melia dubia) under mount planting (6 month old seedlings) is given in Table 5. Melia dubia showed a growth of $244 \mathrm{~cm}$, Terminalia arjuna $209 \mathrm{~cm}$, Hibiscus tiliaceus $209 \mathrm{~cm}$ and Millingtonia hortensis $104 \mathrm{~cm}$. All the four tree species were grown well under mount planting and also under sewage water iriigation. Simultaneously changes in sewage water quality were also recorded (Table 6). There were no traces of ammonia during the 180 days of observation. Reduction in EC of sewage water was noticed $\left(1.33 \mathrm{dS} \mathrm{m}^{-1}\right.$ to $\left.0.96 \mathrm{dS} \mathrm{m}^{-1}\right)$. Reduction in sulphate $(455 \mathrm{mg}$ $\mathrm{L}^{-1}$ to $115 \mathrm{mg} \mathrm{L}^{-1}$ ) were also recorded during this 180 days of observation. There was a slight decline in BOD from 36.50 to $26.80 \mathrm{mg}$ $\mathrm{L}^{-1}$. The changes in microbial load of sewage water across the sewage drain planted with Terminalia arjuna, Millingtonia hortensis,
Hibiscus tiliaceus and Melia dubia were also studied. Specific rhizosphere microbial load of these tree species were also investigated. Terminalia arjuna rhizosphere soil were rich in microflora compared to other species. Hibiscus tiliaceus showed a second high number of microflora followed by other two species.

An artificial lagoon was created with the size of $20^{\prime} \times 20^{\prime} \times 2^{\prime}$ LBD. Six month old seedlings of Terminalia arjuna, Millingtonia hortensis, Hibiscus tiliaceus and Melia dubia were planted at the four corner of the lagoon before the release of sewage water. At the centre of the lagoon a common reed (Phragmites karka) was established in $1 \mathrm{~m}^{2}$ area under raised bed (Bed size $1 \mathrm{ft}$.). The tree species and reeds were allowed to establish for three months. After third month, domestic sewage water was released in to the lagoon. Then, the mixed microbial cultures of Acidithiobacillus ferrooxidans and Acidithiobacillus thiooxidans was added @ $5 \% \mathrm{v} / \mathrm{v}$. Quantity of sewage water can be calculated by volume of sewage flow per unit time (i.e $\mathrm{Q}=\mathrm{A} \times \mathrm{V}$, where $\mathrm{Q}$ is the flow rate, $\mathrm{A}$ is the cross-sectional area at a point in the path of the flow and $\mathrm{V}$ is the velocity of the liquid at that point). No distinct smell of $\mathrm{H}_{2} \mathrm{~S}$ was noticed for about 11 days after the inoculation of microbial mixtures.

From the present investigation it is clearly understood that under aerobic condition, free molecular oxygen is used by microbes as electron acceptor and produce water. Under anaerobic condition, if neither oxygen nor nitrate $\left(\mathrm{NO}_{3}{ }^{-}\right)$is present, microbes tend to use sulphate $\left(\mathrm{SO}_{4}{ }^{2-}\right)$ as electron acceptor and generate $\mathrm{H}_{2} \mathrm{~S}$. Sulphide is present in three forms in sewage water. It usually exists as $\mathrm{H}_{2} \mathrm{~S}$ at low $\mathrm{pH}$, Hydrosulphide ion $\left(\mathrm{HS}^{-}\right)$at neutral $\mathrm{pH}$ and sulphide ion $\left(\mathrm{S}^{2-}\right)$ at high $\mathrm{pH}$. The ionic forms $\left(\mathrm{HS}^{-}, \mathrm{S}^{2-}\right.$ ) stay dissolved in water while $\mathrm{H}_{2} \mathrm{~S}$ is volatilized. 
Table.1 Characteristics of sewage water before and after the treatment by Thiobacillus mixed culture

\begin{tabular}{|c|l|c|c|}
\hline Sl. No. & Parameters & Before treatment & After treatment \\
\hline 1. & $\mathrm{pH}$ & 7.2 & 6.4 \\
\hline 2. & $\mathrm{EC}\left(\mathrm{dS} \mathrm{m}{ }^{-1}\right)$ & 1.23 & 1.38 \\
\hline 3. & COD $\left(\mathrm{mg} \mathrm{L}^{-1}\right)$ & 125 & 68 \\
\hline $\mathbf{4 .}$ & BOD $\left(\mathrm{mg} \mathrm{L}^{-1}\right)$ & 42 & 25 \\
\hline 5. & Dissolved Oxygen $\left(\mathrm{mg} \mathrm{L}^{-1}\right)$ & 3.0 & 3.6 \\
\hline 6. & Sulphate $\left(\mathrm{mg} \mathrm{L}^{-1}\right)$ & 3200 & 98 \\
\hline
\end{tabular}

Table.2 Changes in sewage/river water quality before and after the treatment with Thiobacillus mixed culture

\begin{tabular}{|c|c|c|c|c|c|c|}
\hline \multirow{2}{*}{ Treatments } & \multicolumn{5}{|c|}{ Water quality parameters } \\
\cline { 2 - 7 } & $\mathrm{pH}$ & $\begin{array}{c}\mathrm{EC} \\
\left(\mathrm{dS} \mathrm{m}^{-1}\right)\end{array}$ & $\begin{array}{c}\text { Dissolved Oxygen } \\
\left(\mathrm{mg} \mathrm{L}^{-1}\right)\end{array}$ & $\begin{array}{c}\mathrm{BOD} \\
\left(\mathrm{mg} \mathrm{L}^{-1}\right)\end{array}$ & $\begin{array}{c}\text { COD } \\
\left(\mathrm{mg} \mathrm{L}^{-1}\right)\end{array}$ & $\begin{array}{c}\text { Sulphate } \\
\left(\mathrm{mg} \mathrm{L}^{-1}\right)\end{array}$ \\
\hline T1 & 7.26 & 1.27 & 3.2 & 46 & 135 & 3160 \\
\hline T2 & 7.84 & 0.31 & 8.4 & 0 & 0 & 26 \\
\hline T3 & 6.78 & 1.35 & 2.9 & 51 & 85 & 104 \\
\hline T4 & 7.14 & 0.42 & 4.6 & 26 & 0 & 0 \\
\hline
\end{tabular}

T1 - Sewage water ; T2 - River water; T3 - Sewage water + Thiobacillus mixed culture (Acidithiobacillus ferrooxidans and Acidithiobacillus thiooxidans); T4 - River water + Thiobacillus mixed culture (Acidithiobacillus ferrooxidans and Acidithiobacillus thiooxidans)

Table.3 Comparative evaluation of the vegetative growth of different tree species under sewage/river water irrigation

\begin{tabular}{|l|c|c|c|c|c|c|c|c|c|c|c|c|}
\hline \multirow{2}{*}{$\begin{array}{l}\text { Name of the tree } \\
\text { species }\end{array}$} & \multicolumn{10}{|c|}{ Plant height } \\
\cline { 2 - 15 } & \multicolumn{9}{|c|}{ Sewage water } \\
\cline { 2 - 14 } & Starting & $\mathbf{3 0}$ & $\mathbf{6 0}$ & $\mathbf{9 0}$ & $\mathbf{1 5 0}$ & $\mathbf{1 8 0}$ & Starting & $\mathbf{3 0}$ & $\mathbf{6 0}$ & $\mathbf{9 0}$ & $\mathbf{1 5 0}$ & $\mathbf{1 8 0}$ \\
\hline Hibiscus tiliaceous & 15.0 & 15.8 & 17.1 & 21.0 & 25.1 & 31.5 & 15.0 & 15.8 & 16.9 & 20.0 & 24.6 & 29.5 \\
\hline $\begin{array}{l}\text { Millingtonia } \\
\text { hortensis }\end{array}$ & 15.0 & 15.3 & 16.5 & 18.3 & 20.2 & 23.0 & 15.0 & 15.3 & 16.3 & 18.0 & 19.8 & 22.0 \\
\hline Pongamia pinnata & 15.0 & 15.4 & 17.5 & 19.6 & 25.6 & 31.2 & 15.0 & 15.4 & 17.5 & 20.0 & 26.8 & 32.0 \\
\hline Terminalia arjuna & 15.0 & 15.3 & 16.3 & 18.1 & 24.9 & 31.2 & 15.0 & 15.3 & 15.9 & 17.2 & 24.5 & 29.0 \\
\hline Melia dubia & 15.0 & 16.1 & 23.9 & 31.6 & 59.6 & 121.0 & 15.0 & 15.6 & 22.6 & 30.0 & 55.8 & 116.0 \\
\hline $\begin{array}{l}\text { Neolamarkia } \\
\text { kadamba }\end{array}$ & 15.0 & 15.5 & 24.2 & 29.8 & 46.9 & 91.0 & 15.0 & 15.4 & 24.5 & 32.0 & 48.2 & 98.0 \\
\hline $\begin{array}{l}\text { Azadirachta } \\
\text { indica }\end{array}$ & 15.0 & 15.2 & 20.9 & 26.3 & 29.6 & 39.0 & 15.0 & 15.3 & 21.5 & 26.0 & 31.2 & 42.0 \\
\hline Tespecia populnea & 15.0 & 15.3 & 18.6 & 23.9 & 29.1 & 35.2 & 15.0 & 15.6 & 19.1 & 24.0 & 29.1 & 36.0 \\
\hline Ficus religiosa & 15.0 & 15.2 & 16.0 & 16.0 & 16.5 & 17.5 & 15.0 & 15.2 & 16.0 & 17.0 & 17.4 & 18.0 \\
\hline $\begin{array}{l}\text { Muntingia } \\
\text { Calabura }\end{array}$ & 15.0 & 15.4 & 16.8 & 22.0 & 23.1 & 24.0 & 15.0 & 15.3 & 16.8 & 22.0 & 23.1 & 26.0 \\
\hline
\end{tabular}

$15 \mathrm{~cm}$ height of uniform seedlings were used for the study 
Table.4 Changes in the growth of selected tree species under sewage water irrigation

\begin{tabular}{|l|c|c|c|c|c|c|c|}
\hline \multirow{2}{*}{$\begin{array}{l}\text { Name of the tree } \\
\text { Species }\end{array}$} & \multicolumn{7}{|c|}{ Plant height (cm) } \\
\cline { 2 - 8 } & Starting & $\begin{array}{c}\mathbf{3 0} \\
\text { DAP }\end{array}$ & $\begin{array}{c}\mathbf{6 0} \\
\text { DAP }\end{array}$ & $\begin{array}{c}\mathbf{9 0} \\
\text { DAP }\end{array}$ & $\begin{array}{c}\text { 120 } \\
\text { DAP }\end{array}$ & $\begin{array}{c}\text { 150 } \\
\text { DAP }\end{array}$ & $\begin{array}{c}\text { 180 } \\
\text { DAP }\end{array}$ \\
\hline Hibiscus tiliaceous & 30 & 34.5 & 55.2 & 78.9 & 106.8 & 135.9 & 165.0 \\
\hline $\begin{array}{l}\text { Millingtonia } \\
\text { hortensis }\end{array}$ & 30 & 32.1 & 35.5 & 46.2 & 52.2 & 61.5 & 76.0 \\
\hline Terminalia arjuna & 30 & 33.6 & 61.5 & 86.5 & 120.5 & 141.2 & 165.0 \\
\hline Melia dubia & 30 & 32.9 & 78.9 & 100.2 & 138.2 & 165.2 & 190.0 \\
\hline
\end{tabular}

Table.5 Changes in growth of selected tree species under mount planting across the natural sewage drains

\begin{tabular}{|c|c|c|c|c|c|c|c|c|}
\hline \multirow{2}{*}{$\begin{array}{l}\text { Name of the } \\
\text { tree species }\end{array}$} & \multirow{2}{*}{$\begin{array}{l}\text { Common } \\
\text { name }\end{array}$} & \multicolumn{7}{|c|}{ Plant height (cm) } \\
\hline & & $\begin{array}{l}\text { Starting } \\
6 \text { month old } \\
\text { seedling }\end{array}$ & $\begin{array}{c}30 \\
\text { DAP }\end{array}$ & $\begin{array}{c}60 \\
\text { DAP }\end{array}$ & $\begin{array}{c}90 \\
\text { DAP }\end{array}$ & $\begin{array}{c}120 \\
\text { DAP }\end{array}$ & $\begin{array}{c}150 \\
\text { DAP }\end{array}$ & $\begin{array}{r}180 \\
\text { DAP }\end{array}$ \\
\hline $\begin{array}{l}\text { Hibiscus } \\
\text { tiliaceous }\end{array}$ & $\begin{array}{l}\text { Malai } \\
\text { Poovarasu }\end{array}$ & 165 & 169 & 178 & 191 & 198 & 201 & 209 \\
\hline $\begin{array}{l}\text { Millingtonia } \\
\text { hortensis }\end{array}$ & Maramalli & 76 & 78 & 84 & 90 & 93 & 98 & 104 \\
\hline $\begin{array}{l}\text { Terminalia } \\
\text { arjuna }\end{array}$ & $\begin{array}{l}\text { Neer } \\
\text { marudhu }\end{array}$ & 165 & 170 & 182 & 205 & 211 & 217 & 231 \\
\hline Melia dubia & Malaivembu & 190 & 197 & 212 & 222 & 229 & 237 & 244 \\
\hline
\end{tabular}

Table.6 Changes in sewage water quality parameters of sewage drain with trees

\begin{tabular}{|c|c|c|c|c|c|c|c|}
\hline Drain with Trees & Initial & $\begin{array}{c}30 \\
\text { DAP }\end{array}$ & $\begin{array}{c}60 \\
\text { DAP }\end{array}$ & $\begin{array}{c}90 \\
\text { DAP }\end{array}$ & $\begin{array}{c}120 \\
\text { DAP }\end{array}$ & 150 DAP & $\begin{array}{c}180 \\
\text { DAP }\end{array}$ \\
\hline pH & 7.33 & 7.24 & 7.33 & 7.02 & 7.15 & 7.22 & 7.17 \\
\hline $\operatorname{EC}\left(d S ~ m^{-1}\right)$ & 1.33 & 1.08 & 1.11 & 1.01 & 1.06 & 0.98 & 0.96 \\
\hline $\begin{array}{l}\text { Dissolved Oxygen } \\
\left(\mathrm{mg} \mathrm{L}^{-1}\right)\end{array}$ & 3.13 & 5.20 & 6.50 & 6.80 & 7.20 & 7.90 & 7.80 \\
\hline BOD $\left(\mathrm{mg} \mathrm{L}^{-1}\right)$ & 36.00 & 32.00 & 26.00 & 25.00 & 28.00 & 24.00 & 26.00 \\
\hline Sulphates $\left(\mathrm{mg} \mathrm{L}^{-1}\right)$ & 455.00 & 400.00 & 380.00 & 256.00 & 140.00 & 135.00 & 115.00 \\
\hline Chloride (mg L $\left.\mathbf{L}^{-1}\right)$ & 42.00 & 48.00 & 46.00 & 42.00 & 48.00 & 46.00 & 48.00 \\
\hline $\operatorname{TDS}\left(\mathrm{mg} \mathrm{L}^{-1}\right)$ & 870.00 & 798.00 & 825.00 & 790.00 & 795.00 & 765.00 & 752.00 \\
\hline Ammonia (mg L $\left.\mathrm{L}^{-1}\right)$ & 0 & 0 & 0 & 0 & 0 & 0 & 0 \\
\hline
\end{tabular}

Values are mean of three observations 
Table.7 Changes in water quality parameters of sewage drain without trees

\begin{tabular}{|c|c|c|c|c|c|c|c|}
\hline Drain without Trees & Initial & $\begin{array}{c}\text { 30 } \\
\text { DAP }\end{array}$ & $\begin{array}{c}60 \\
\text { DAP }\end{array}$ & $\begin{array}{c}90 \\
\text { DAP }\end{array}$ & $\begin{array}{l}120 \\
\text { DAP }\end{array}$ & 150 DAP & $\begin{array}{l}180 \\
\text { DAP }\end{array}$ \\
\hline pH & 7.31 & 7.31 & 7.33 & 7.25 & 7.25 & 7.39 & 7.37 \\
\hline$E C\left(d S m^{-1}\right)$ & 1.23 & 1.21 & 1.18 & 1.25 & 1.33 & 1.28 & 1.29 \\
\hline $\begin{array}{l}\text { Dissolved Oxygen } \\
\left(\mathrm{mg} \mathrm{L}^{-1}\right)\end{array}$ & 3.13 & 4.12 & 3.55 & 2.58 & 3.12 & 2.95 & 2.80 \\
\hline BOD $\left(\mathrm{mg} \mathrm{L}^{-1}\right)$ & 36 & 32 & 35 & 44 & 55 & 60 & 55 \\
\hline Sulphates $\left(\mathrm{mg} \mathrm{L}^{-1}\right)$ & 455 & 480 & 478 & 490 & 520 & 498 & 510 \\
\hline Chloride (mg L $\left.{ }^{-1}\right)$ & 46.00 & 54.00 & 46.00 & 42.00 & 46.00 & 46.00 & 46.00 \\
\hline TDS $\left(\mathrm{mg} \mathrm{L}^{-1}\right)$ & 790.00 & 775.00 & 750.00 & 798.00 & 855.00 & 810.00 & 810.00 \\
\hline $\operatorname{Ammonia}\left(\mathrm{mg} \mathrm{L}^{-1}\right)$ & 0 & 0 & 0 & 0 & 0 & 0 & 0 \\
\hline
\end{tabular}

Values are mean of three observations

Thus cause odour problem. The usual practice adopted by much sewage treatment plant is vigorous aeration. The oxidation of $\mathrm{H}_{2} \mathrm{~S}$ under highly aerobic condition generates sulphuric acid. But, a group of bacteria, sulphur bacteria oxidize $\mathrm{H}_{2} \mathrm{~S}$ into elemental sulphur without producing sulphuric acid. $\mathrm{H}_{2} \mathrm{~S}+\mathrm{CO}_{2}=\mathrm{S}^{\mathrm{O}}+$ $\mathrm{CH}_{2} \mathrm{O}$. This elemental sulphur is not used by sulphate reducing bacteria. Thus disrupts the cycle by arresting the formation of $\mathrm{H}_{2} \mathrm{~S}$. Thiobacillus ferrooxidans and Thiobacillus thiooxidans in combination play a perfect role in oxidizing the $\mathrm{H}_{2} \mathrm{~S}$ into elemental sulphur thus it prevents odour from sewage water. During summer, odour control is a big problem.

The activity of microbes will be more and they might require more oxygen. The increase in microbial activity depletes the oxygen and makes the bacteria to look for an alternative oxygen source alleviate an odour problem. Bacteria generally go for free oxygen at first. In the event of non-availability of oxygen it prefers nitrates, then sulphates. So addition of sodium nitrate would also solve the odour problem. Addition of Thiobacillus blend would convert $\mathrm{H}_{2} \mathrm{~S}$ into elemental sulphur in case of non-availability of nitrates. The trees that we recommend would keep the sewage system aerated and solve odour problem.
When the tree system fails to reduce odour, application of sodium nitrate would solve the problem. When these two systems fails, the introduced Thiobacillus bacterial blend would convert $\mathrm{H}_{2} \mathrm{~S}$ into elemental sulphur which cannot be used by sulphur reducing bacteria, thus permanently arresting the odour problem.

Present study confirms, Terminalia arjuna, Millingtonia hortensis, Hibiscus tiliaceus and Melia dubia can be successfully planted across the sewage drain (open channel) as their growth was not affected due to excess sewage. In turn, the root system of these plants are also supported the growth of Acidithiobacillus ferrooxidans and Acidithiobacillus thiooxidans.s Sewage odour can be controlled by the addition of mixed cultures of Acidithiobacillus ferrooxidans and Acidithiobacillus thiooxidans and planting of Terminalia arjuna, Millingtonia hortensis, Hibiscus tiliaceus and Melia dubia.

Under lagoon condition, in addition to the above, Phragmites karka and Brachiaria mutica can be used as biofloating mat to supply oxygen and remove excess odour. The trees (Terminalia arjuna, Millingtonia hortensis, Hibiscus tiliaceus and Melia dubia) would keep the sewage system aerated and solve odour problem. 


\section{References}

Boon, A.G. 1995. Septicity in sewers: causes, consequences and containment. Water Science and Technology. 31(7), 237253.

CEN. 1999. Air quality - determination of odour concentration measurement by dynamic olfactometry. European Committee for Standardization, draft prEN. 13725.

Gostelow, P., and Parsons. S.A. 2000. Sewage treatment works odour measurement. Water Science and Technology. 41(6), 33-40.

Gostelow, P., Parsons, S. A., and Stwetz, R. M. 2001. Odour measurements for sewage treatment works. Water Research. 35, 579-597.

Hvitved-Jacobsen, T., Vollertsen, J., and Tanaka, N. 1999. An integrated aerobic/anaerobic approach for prediction of sulfides in sewers. Water Science and Technology. 41(6), 107116.

Hwang, Y., Matsuo, T., Hanaki, K., and Suzuki, N. 1995. Identification and quantification of sulfur and nitrogen containing odorous compounds in wastewater. Water Research. 29(2), 711-718.

Lens, P. N., De Poorte, M. P., Cronenberg, C.C., and Verstraete, W.H. 1995. Sulfate reducing and methane producing bacteria in aerobic wastewater treatment systems. Water Research. 29(3), 871880.

Livermore, A., and Laing, D. G. 1998. The influence of chemical complexity on the perception of multicomponent odor mixtures. Percept. Psychophys. (60), 650-661.

Sneath, R.W., and C. Clarkson. 2000. Odour measurement: A code of practice, Water Science and Technology. 41(6), 23-31.

Stuetz, R.M., Fenner, R.A., Hall, S.J., Stratful I., and D. Loke. 2000. Monitoring of wastewater odours using an electronic nose, Water Science and Technology. 41(6), 41-47.

Suffet, I. H., Burlingame, G. A., Rosenfeld, P. E., and Bruchet, A. 2004. The value of an odor-quality-wheel classification scheme for wastewater plants. Water Science and Technology. 50(4), 25-32.

Thistlethwayte, D.K.B., and E.E. Goleb. 1972. The composition of sewer air, proceedings from the 6th International Conference on Water Pollution Research, Israel, June 1972, 281-289.

Thorkild Hvitved-Jacobsen, Jes Vollertsen and Asbjørn Haaning Nielsen 2005. Odor from sewer networks - processes and prediction 9th NORDIWA Conference, Stockholm, Sweden, November 7-9, 2005.

\section{How to cite this article:}

Prasanthrajan. M., A. Balasubramanian and Parthiban. K. T. 2020. Odour Abatement in Sewage Water: A Tree Based Biological Approach. Int.J.Curr.Microbiol.App.Sci. 9(06): 20412050. doi: https://doi.org/10.20546/ijcmas.2020.906.251 